\title{
Glycated Albumin Levels in Patients with Type 2 Diabetes Increase Relative to $\mathbf{H b A}_{1 \mathrm{c}}$ with Time
}

\author{
Hye-jin Yoon, ${ }^{1,2}$ Yong-ho Lee, ${ }^{1,2}$ Kwang Joon Kim, ${ }^{3}$ So Ra Kim, ${ }^{1,2}$ Eun Seok Kang, ${ }^{1,2}$ \\ Bong-Soo Cha, ${ }^{1,2}$ Hyun Chul Lee, ${ }^{1,2}$ and Byung-Wan Lee ${ }^{1,2}$ \\ ${ }^{1}$ Division of Endocrinology and Metabolism, Department of Internal Medicine, Yonsei University College of Medicine, \\ Seoul 120-752, Republic of Korea \\ ${ }^{2}$ Severance Hospital, Seoul, Republic of Korea \\ ${ }^{3}$ Severance Executive Healthcare Clinic, Yonsei University Health System, Seoul, Republic of Korea
}

Correspondence should be addressed to Byung-Wan Lee; bwanlee@yuhs.ac

Received 25 June 2015; Revised 29 August 2015; Accepted 9 September 2015

Academic Editor: Yoshifumi Saisho

Copyright (C) 2015 Hye-jin Yoon et al. This is an open access article distributed under the Creative Commons Attribution License, which permits unrestricted use, distribution, and reproduction in any medium, provided the original work is properly cited.

\begin{abstract}
We recently reported that glycated albumin (GA) is increased in subjects with longer duration of diabetes and with decreased insulin secretory function. Based on this, we investigated whether GA increases with time relative to glycated hemoglobin $\left(\mathrm{HbA}_{1 c}\right)$ and the association between GA and beta-cell function. We analyzed 340 type 2 diabetes patients whose serum GA and HbAlc levels had been repeatedly measured over 4 years. We assessed the pattern of changes with time in glycemic indices $\left(\mathrm{GA}, \mathrm{HbA}_{1 \mathrm{c}}\right.$ and $\mathrm{GA} / \mathrm{HbA}_{1 \mathrm{c}}$ ratio) and their relationship with beta-cell function. In all patients, glycemic indices decreased and maintained low levels around 15 and 27 months. However, from 39 months to 51 months, GA significantly increased but $\mathrm{HbA}_{1 \mathrm{c}}$ tended to increase without statistical significance. We defined $\Delta \mathrm{GA} / \mathrm{HbA}_{1 \mathrm{c}}$ as the difference between the nadir point (at 15 to 27 months) and the end point (at 39 to 51 months) and found that $\Delta \mathrm{GA} / \mathrm{HbA}_{1 \mathrm{c}}$ was positively correlated with diabetes duration and negatively related to beta-cell function. In multivariable linear regression analyses, $\Delta \mathrm{GA} / \mathrm{HbA}_{1 \mathrm{c}}$ was independently associated with diabetes duration. In conclusion, this study demonstrated that serum GA levels increase relative to $\mathrm{HbA}_{1 \mathrm{c}}$ levels with time.
\end{abstract}

\section{Introduction}

Glucose monitoring is essential for the appropriate care and treatment of patients with diabetes in order to avoid diabetic complications and hypoglycemia. An accurate measure of glucose level allows physicians and patients to make optimal decisions about food, physical activity, and medications [1]. Of the glycemic indices, the American Diabetes Association recommends glycated hemoglobin $\left(\mathrm{HbA}_{1 \mathrm{c}}\right)$ testing in all diabetic patients as an initial assessment and then as a part of continuing care [2]. This recommendation is derived from clinical data that shows that $\mathrm{HbA}_{1 \mathrm{c}}$ reflects average glycemic status over 2-3 months and predicts diabetic complications $[3,4]$. Although $\mathrm{HbA}_{1 \mathrm{c}}$ provides useful information, it might be inadequate in clinical situations such as anemia, renal insufficiency, and gestational diabetes. Glycated albumin
(GA) has been gaining popularity as an indicator in several physiologic and pathologic conditions [5] because it provides more information than the gold standard $\mathrm{HbA}_{1 \mathrm{c}}$. In line with this trend, we have demonstrated the clinical relevance of GA in type 2 diabetes mellitus (T2D) with insulin secretory dysfunction rather than insulin resistance [6], fluctuating or poorly controlled glycemic excursions [7], and progressing atherosclerosis [8].

In the natural course of $\mathrm{T} 2 \mathrm{D}$, however, beta-cell function decreases as duration of diabetes increases [9]. Moreover, glycemic excursions worsen due to decreased beta-cell function [10]. In a recent cross-sectional study, we reported that the levels of $\mathrm{GA} / \mathrm{HbA}_{1 \mathrm{c}}$ were significantly elevated in subjects with long diabetic duration, largely attributed to the inverse relationships between GA and pancreatic beta-cell secretory indices [11], and suggested that clinicians should be careful 
in interpreting GA as only an indicator of glycemic control in T2D cases of longer duration. However, no longitudinal studies investigating the change in $\mathrm{GA}$ and $\mathrm{HbA}_{1 \mathrm{c}}$ over time in patients with T2D have been published.

In this longitudinal observational study, we investigated the changing pattern of glycemic indices such as $\mathrm{GA}, \mathrm{HbA}_{1 \mathrm{c}}$, and $\mathrm{GA} / \mathrm{HbA}_{1 \mathrm{c}}$ over 4 years in order to determine whether GA increases more with time relative to $\mathrm{HbA}_{1 \mathrm{c}}$ in subjects with T2D. We also investigated which clinical and biochemical parameters are associated with changes in the $\mathrm{GA} / \mathrm{HbA}_{1 \mathrm{c}}$ ratio.

\section{Research Design and Methods}

2.1. Subjects and Data Collection. In this longitudinal observational study, we recruited patients with T2D who had enrolled in previous studies [6, 7] between May 2009 and June 2011 and who were followed up in June 2014. Using electronic medical records, we reviewed and rechecked demographic and clinical data for age, gender, metabolic parameters, and duration of diabetes. The diabetic duration was defined from the date the patients were first diagnosed with diabetes by blood tests or by patient recall from interviews.

To investigate the changes in glycemic indices with time, we tried to include patients whose duration of diabetes was less than 5 years. Patients were included if they were (1) aged $\geq 20$ years, (2) had repeated laboratory data for both $\mathrm{HbA}_{1 \mathrm{c}}$ and GA up to the final follow-up point, and (3) had undergone a baseline standardized liquid meal test (Ensure, Meiji Dairies Corporation, Tokyo, Japan; $500 \mathrm{kcal}, 17.5 \mathrm{~g}$ fat (31.5\%), $68.5 \mathrm{~g}$ carbohydrate $(54.5 \%)$, and $17.5 \mathrm{~g}$ protein $(14.0 \%))$ after an overnight fast. Patients were excluded if they had any medical conditions that could alter $\mathrm{HbA}_{1 \mathrm{c}}$ or GA levels such as liver cirrhosis or chronic kidney diseases (estimated glomerular filtration rate (GFR) by chronic kidney disease epidemiology collaboration formula $<60 \mathrm{~mL} / \mathrm{min} / 1.73 \mathrm{~m}^{2}$ ), pregnancy, or hematologic disorders or if they were being treated with steroids.

The protocol of this study was approved by the Institutional Review Board at Severance Hospital (IRB numbers 4-2009-0656, 4-2012-0398, and 4-2014-0507). Written informed consent for this study was not required by the Institutional Review Board because researchers only accessed the database for analysis purposes, and personal information was not used.

2.2. Laboratory Measurements. The baseline glycemic indices $\left(\mathrm{GA}, \mathrm{HbA}_{1 \mathrm{c}}\right.$, and $\mathrm{GA} / \mathrm{HbA}_{1 \mathrm{c}}$ ) were defined as the values measured at enrollment. Subsequently, serum GA and $\mathrm{HbA}_{1 \mathrm{c}}$ were measured every 3 or 6 months. The end point glycemic indices of each subject were measured between 39 and 51 months. For glucose and C-peptide analyses, blood samples were collected at 0 and $90 \mathrm{~min}$ (basal and stimulated values) as part of the standardized liquid meal test. Pancreatic betacell functions in the context of ambient insulin secretory function were assessed using the following indices: (1) PCGR (stimulated C-peptide level/stimulated glucose level $\times$
100), (2) C-peptide increment $(\Delta \mathrm{C}$-peptide $=$ stimulated $\mathrm{C}$ peptide - basal C-peptide), and (3) C-peptide-genic index [CGI = (stimulated C-peptide - basal C-peptide) $/($ stimulated glucose - basal glucose)]. Measurement techniques included the hexokinase method for glucose and high-performance liquid chromatography using Variant II Turbo (Bio-Rad Laboratories, Hercules, CA) for $\mathrm{HbA}_{1 \mathrm{c}}$. Serum GA was analyzed by an enzymatic method using an albumin-specific proteinase, ketoamine oxidase, an albumin assay reagent (LUCICA GA-L; Asahi Kasei Pharma Co., Tokyo, Japan), and a Hitachi 7699 P module autoanalyzer (Hitachi Instruments Service, Tokyo, Japan). GA values were calculated from the ratio of GA to total serum albumin and expressed as a percentage. Serum C-peptide levels were measured in duplicate using an immunoradiometric assay method (Beckman Coulter, Fullerton, CA).

2.3. Statistical Analysis. All continuous variables were presented as mean \pm standard deviation (SD) or median (quartiles) or as mean \pm standard error (SE) for variables on the graphs. Categorical variables were described as $N$ (\%). Differences were analyzed using Student's $t$-test for the continuous variables and the chi-square test for categorical variables.

Repeated measured analysis of variance (ANOVA) with Bonferroni correction and paired $t$-test were used to determine the significance of differences in glycemic indices according to duration of diabetes. We compared $\mathrm{GA}, \mathrm{HbA}_{1 \mathrm{c}}$, and $\mathrm{GA} / \mathrm{HbA}_{1 \mathrm{c}}$ levels at baseline and $3,15,27$, and 39 to 51 months after enrollment in all patients who had glycemic values available at that time point. Because all glycemic indices reached their lowest level between 15 and 27 months (arbitrarily defined nadir point), we defined $\Delta \mathrm{GA} / \mathrm{HbA}_{1 \mathrm{c}}$ as the difference in $\mathrm{GA} / \mathrm{HbA}_{1 \mathrm{c}}$ between the end point (39 to 51 months) and nadir point (15 to 27 months). One-way ANOVA with Tukey correction was used to compare the differences of duration of diabetes and PCGR according to the tertiles of $\Delta \mathrm{GA} / \mathrm{HbA}_{1 \mathrm{c}}$ ratio. Multivariable linear regression analysis was performed to determine the independent relationship of the studied variables including duration of diabetes associated with $\triangle \mathrm{GA} / \mathrm{HbA}_{1 \mathrm{c}}$ increase. Statistical analyses were performed using PASW Statistics version 18.0 for Windows (SPSS Inc., Chicago, IL, USA).

\section{Results}

3.1. Study Population Characteristics. A total of 340 subjects (71\% men, mean age $61.3 \pm 11.6$ years) were enrolled in this study. The patient characteristics of the cohort are shown in Table 1. The mean body mass index (BMI) was $25.4 \pm$ $3.6 \mathrm{~kg} / \mathrm{m}^{2}$ and the prevalence of hypertension was $57 \%(n=$ 195). Median duration of diabetes and levels of mean $\mathrm{HbA}_{1 \mathrm{c}}$ were 1 (range: $0-5.0$ ) year and $7.0 \%+0.9 \%$, respectively. We also measured baseline insulin secretory beta-cell function indices such as PCGR $(3.24 \pm 2.1), \Delta$ C-peptide level $(4.13 \pm$ 2.6), and CGI (0.08 \pm 0.4$)$. All glycemic indices, GA $(19.3 \pm 6.6$ versus $16.5 \pm 4.9), \mathrm{HbA}_{1 \mathrm{c}}(7.7 \pm 1.6$ versus $7.0 \pm 1.2)$, and $\mathrm{GA} / \mathrm{HbA}_{1 \mathrm{c}}(2.47 \pm 0.5$ versus $2.33 \pm 0.4)$, were decreased at 
TABLE 1: Baseline characteristics of the study population.

\begin{tabular}{|c|c|}
\hline Variables & All $(N=340)$ \\
\hline \multicolumn{2}{|l|}{ Demographics } \\
\hline Age (years) & $61.3 \pm 11.6$ \\
\hline Male, $N(\%)$ & $204(71)$ \\
\hline BMI $\left(\mathrm{kg} / \mathrm{m}^{2}\right)$ & $25.4 \pm 3.6$ \\
\hline Waist circumference $(\mathrm{cm})$ & $88.1 \pm 9.0$ \\
\hline Hypertension, $N(\%)$ & $195(57)$ \\
\hline Duration of diabetes (years) & $1.0(0-5.0)$ \\
\hline \multicolumn{2}{|l|}{ Biochemistry profiles } \\
\hline Creatinine (mg/dL) & $0.93 \pm 0.2$ \\
\hline Estimated GFR $\left(\mathrm{mL} / \mathrm{min} / 1.73 \mathrm{~m}^{2}\right)$ & $81.5 \pm 17.7$ \\
\hline Albumin $(\mathrm{g} / \mathrm{dL})$ & $4.6 \pm 0.4$ \\
\hline Total cholesterol (mg/dL) & $177.2 \pm 48.5$ \\
\hline Triglyceride (mg/dL) & $152.5 \pm 110.7$ \\
\hline HDL-cholesterol (mg/dL) & $47.7 \pm 14.3$ \\
\hline LDL-cholesterol (mg/dL) & $99.7 \pm 38.7$ \\
\hline \multicolumn{2}{|l|}{ Beta-cell function indices at baseline } \\
\hline Basal glucose (mg/dL) & $138.0 \pm 50.9$ \\
\hline Stimulated glucose (mg/dL) & $231.8 \pm 87.3$ \\
\hline Basal C-peptide (ng/mL) & $2.35 \pm 1.2$ \\
\hline Stimulated C-peptide (ng/mL) & $6.50 \pm 3.3$ \\
\hline$\Delta \mathrm{C}$-peptide (ng/ml) & $4.13 \pm 2.6$ \\
\hline PCGR & $3.24 \pm 2.1$ \\
\hline CGI & $0.08 \pm 0.4$ \\
\hline \multicolumn{2}{|l|}{ Glycemic indices } \\
\hline GA at baseline (\%) & $19.3 \pm 6.6$ \\
\hline $\mathrm{HbA}_{1 \mathrm{c}}$ at baseline $(\%)$ & $7.7 \pm 1.6$ \\
\hline $\mathrm{HbA}_{\mathrm{lc}}$ at baseline $(\mathrm{mmol} / \mathrm{mol})$ & $60.8 \pm 16.9$ \\
\hline $\mathrm{GA} / \mathrm{HbA}_{\mathrm{lc}}$ ratio at baseline & $2.47 \pm 0.5$ \\
\hline GA at end point (\%) & $16.5 \pm 4.9$ \\
\hline $\mathrm{HbA}_{1 \mathrm{c}}$ at end point (\%) & $7.0 \pm 1.2$ \\
\hline $\mathrm{HbA}_{\mathrm{lc}}$ at end point $(\mathrm{mmol} / \mathrm{mol})$ & $53.2 \pm 13.1$ \\
\hline $\mathrm{GA} / \mathrm{HbA}_{\mathrm{lc}}$ ratio at end point & $2.33 \pm 0.4$ \\
\hline Mean GA (\%) & $16.5 \pm 4.0$ \\
\hline Mean $\mathrm{HbA}_{\mathrm{lc}}(\%)$ & $7.0 \pm 0.9$ \\
\hline \multicolumn{2}{|l|}{ Medications at baseline } \\
\hline Insulin, $N(\%)$ & $63(19)$ \\
\hline Metformin, $N(\%)$ & $221(65)$ \\
\hline DPP-IV inhibitor, $N(\%)$ & $59(17)$ \\
\hline Thiazolidinediones, $N(\%)$ & $40(12)$ \\
\hline Sulfonylurea, $N(\%)$ & $88(26)$ \\
\hline \multicolumn{2}{|l|}{ Medications at 27 months } \\
\hline Insulin, $N(\%)$ & $52(15)$ \\
\hline Metformin, $N(\%)$ & $254(75)$ \\
\hline DPP-IV inhibitor, $N(\%)$ & $98(29)$ \\
\hline Thiazolidinediones, $N(\%)$ & $65(19)$ \\
\hline Sulfonylurea, $N(\%)$ & $99(29)$ \\
\hline
\end{tabular}

Continuous variables were described as mean \pm SD or median (quartiles), $N$ (\%) for categorical variables.

BMI, body mass index; GFR, glomerular filtration rate; GA, glycated albumin; CGI, C-peptide-genic index; PCGR, postprandial C-peptide to glucose ratio.

final follow-up compared to those at baseline. At the time of enrollment, the patients were being treated with metformin (221 patients; $65 \%$ of the study population), sulfonylurea ( 88 ; $26 \%)$, DPP-IV inhibitors $(59 ; 17 \%)$, or insulin $(63 ; 19 \%)$.
TABLE 2: Univariate linear regression analysis to determine the variables associated with $\triangle \mathrm{GA} / \mathrm{HbA}_{1 \mathrm{c}}$.

\begin{tabular}{|c|c|c|}
\hline Variables & $\operatorname{STD} \beta$ & $p$ \\
\hline Age (year) & 0.063 & 0.246 \\
\hline $\operatorname{BMI}\left(\mathrm{kg} / \mathrm{m}^{2}\right)$ & -0.063 & 0.251 \\
\hline Waist circumference $(\mathrm{cm})$ & 0.004 & 0.940 \\
\hline Estimated GFR $\left(\mathrm{mL} / \mathrm{min} / 1.73 \mathrm{~m}^{2}\right)$ & -0.032 & 0.552 \\
\hline Albumin (g/dL) & 0.008 & 0.886 \\
\hline Total cholesterol (mg/dL) & -0.029 & 0.599 \\
\hline Triglyceride (mg/dL) & -0.080 & 0.141 \\
\hline HDL-cholesterol (mg/dL) & 0.023 & 0.674 \\
\hline LDL-cholesterol (mg/dL) & -0.007 & 0.903 \\
\hline GA at baseline (\%) & 0.166 & 0.002 \\
\hline $\mathrm{HbA}_{1 \mathrm{c}}$ at baseline $(\%)$ & 0.017 & 0.753 \\
\hline Mean GA (\%) & 0.345 & $<0.001$ \\
\hline Mean $\mathrm{HbA}_{1 \mathrm{c}}(\%)$ & 0.128 & 0.018 \\
\hline Duration of diabetes (year) & 0.187 & 0.001 \\
\hline$\Delta \mathrm{C}$-peptide $(\mathrm{ng} / \mathrm{mL})$ & -0.139 & 0.011 \\
\hline PCGR & -0.145 & 0.007 \\
\hline CGI & -0.059 & 0.284 \\
\hline
\end{tabular}

BMI, body mass index; GFR, glomerular filtration rate; GA, glycated albumin; PCGR, postprandial C-peptide to glucose ratio; CGI, C-peptidegenic index. Values with statistical significance are printed in bold.

3.2. Glycated Albumin and $\mathrm{GA} / \mathrm{Hb} A_{1 c}$ Ratio Levels Increased Relative to $\mathrm{HbA}_{1 c}$ Levels over Time. In all patients, both levels of GA $(16.1 \% \pm 4.0 \%)$ and $\mathrm{GA} / \mathrm{HbA}_{1 \mathrm{c}}$ ratio $(2.30 \pm 0.4)$ improved and reached the nadir points on glucose control at 15 months (Figure 1). From 15 months to 39 months, the nadir glycemic indices were stably maintained. From 39 months to 51 months, GA significantly increased $(16.1 \% \pm 4.8 \%$ to $17.5 \% \pm 4.9 \%, p=0.028)$, but $\mathrm{HbA}_{1 \mathrm{c}}$ tended to increase without statistical significance $(6.9 \% \pm 1.0 \%$ to $7.1 \% \pm 1.2 \%$, $p=0.389)$. The levels of GA at 27 and 39 months $(p=0.029$ and 0.028 , resp.) as well as $\mathrm{GA} / \mathrm{HbA}_{1 \mathrm{c}}$ ratio at 15 and 27 months $(p=0.038, p=0.039)$ were significantly lower than at 51 months (Figures 1(a) and 1(b)). However, statistical differences in $\mathrm{HbA}_{1 \mathrm{c}}$ between each time point $(3,15,27$, and 39 months) and the last time point (51 months) were not significant except for baseline (Figure 1(c)). In sum, GA levels and the $\mathrm{GA} / \mathrm{HbA}_{1 \mathrm{c}}$ ratio, but not $\mathrm{HbA}_{1 \mathrm{c}}$ levels, were significantly increased at the final follow-up compared with those at the nadir time point (Figure $1(\mathrm{~d})$ ).

3.3. Associations between $\triangle G A / H b A_{1 c}$ and Clinical and Biochemical Parameters. Since the $\mathrm{GA} / \mathrm{HbA}_{1 \mathrm{c}}$ ratio significantly increased from the nadir point to the final follow-up point, which was designated as $\Delta \mathrm{GA} / \mathrm{HbA}_{1 \mathrm{c}}$ (Figure $1(\mathrm{e})$ ), we tried to determine the clinical and biochemical parameters that are associated with $\Delta \mathrm{GA} / \mathrm{HbA}_{1 \mathrm{c}}$ (Table 2). In the univariate linear regression analysis, duration of diabetes (standardized $\beta$ coefficient (STD $\beta)=0.187, p=0.001$ ), mean GA (STD $\beta=0.345, p<0.001$ ), and mean $\mathrm{HbA}_{1 \mathrm{c}}$ (STD $\beta=0.128$, $p=0.018$ ) were positively associated with $\Delta \mathrm{GA} / \mathrm{HbA}_{1 \mathrm{c}}$. On the other hand, beta-cell function indices were negatively related to $\Delta \mathrm{GA} / \mathrm{HbA}_{1 \mathrm{c}}$. In particular, $\mathrm{PCGR}(\mathrm{STD} \beta=-0.145$, 


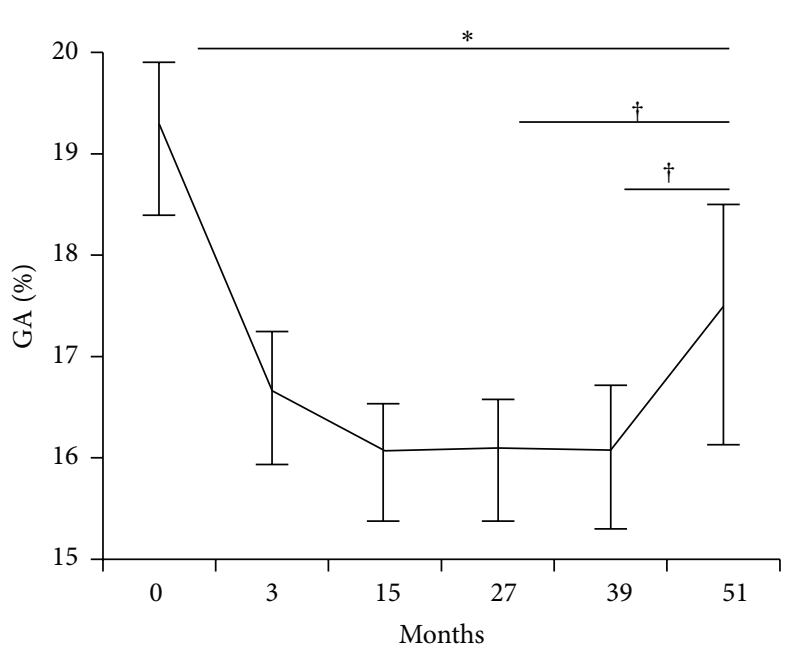

(a)

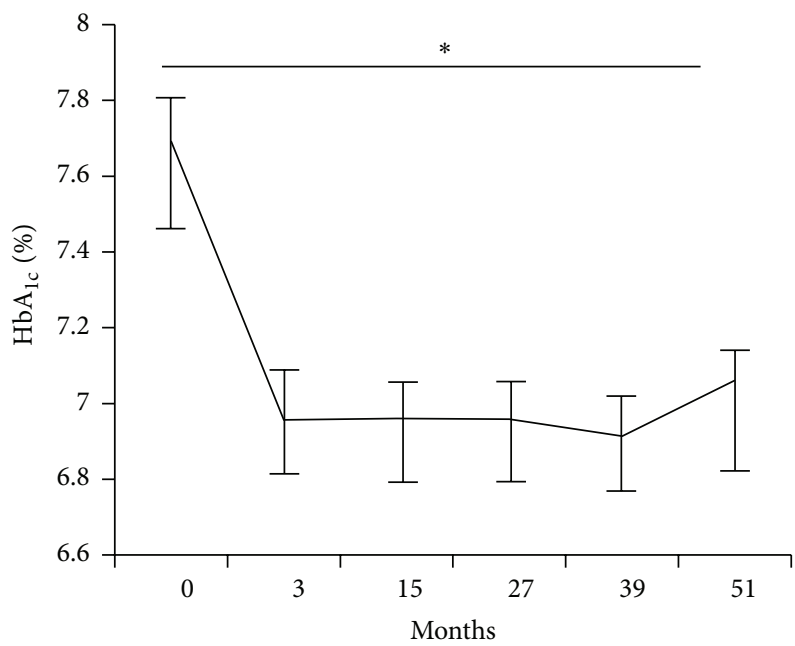

(c)

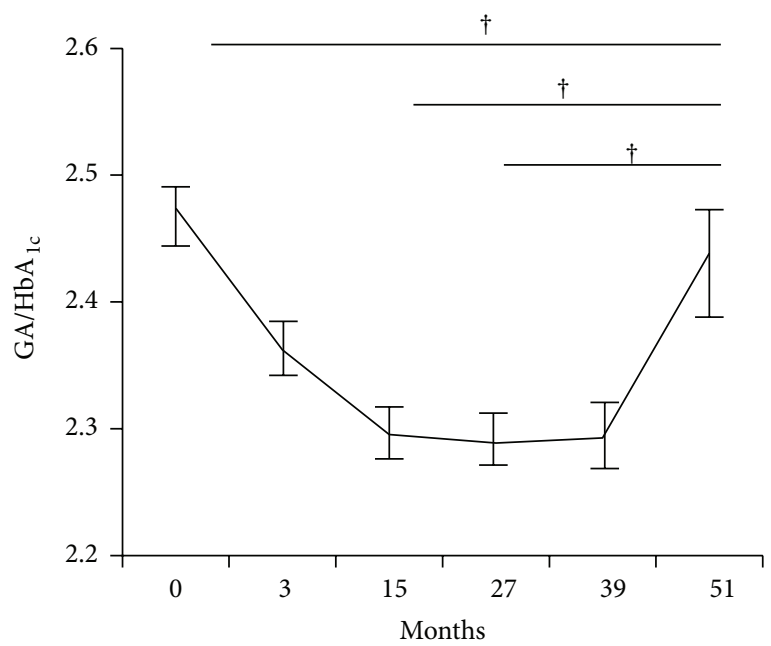

(b)

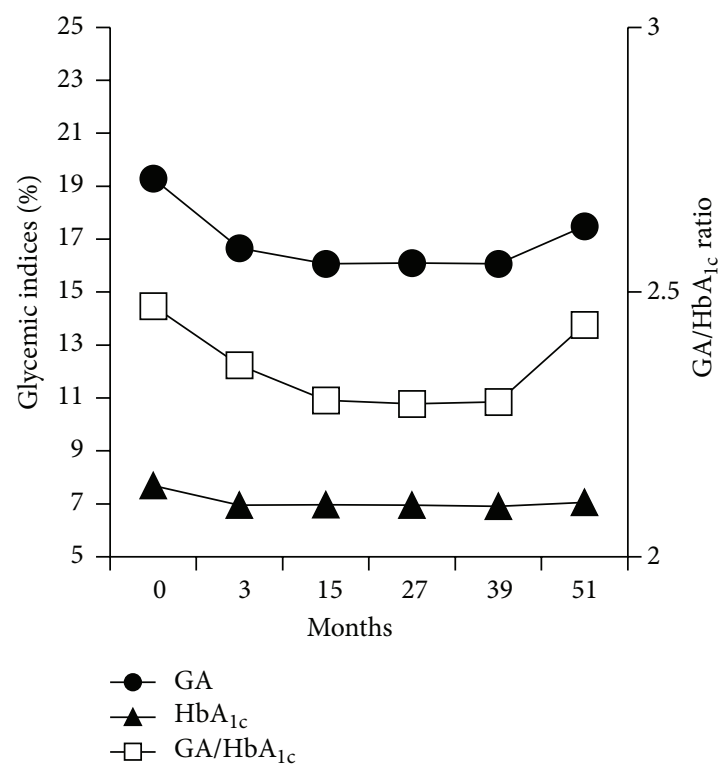

(d)

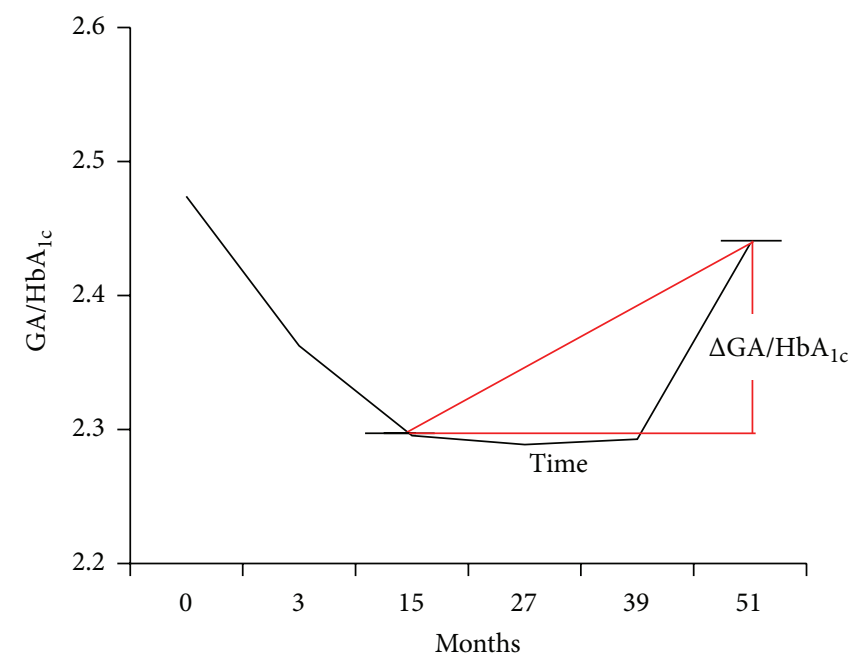

(e)

Figure 1: Changing patterns of glycemic indices over 4 years. (a) GA, (b) GA/HbA $1 \mathrm{catio}$, (c) $\mathrm{HbA}_{1 \mathrm{c}}$, (d) changing patterns of glycemic indices, (e) $\Delta \mathrm{GA} / \mathrm{HbA}_{1 \mathrm{c}}$, calculated by end point $\mathrm{GA} / \mathrm{HbA}_{1 \mathrm{c}}$ - nadir point $\mathrm{GA} / \mathrm{HbA}_{1 \mathrm{c}}$. Data are presented as mean with SE. ${ }^{*} p<0.001$, ${ }^{\dagger} p<0.05$ for the comparison with 51 months. 


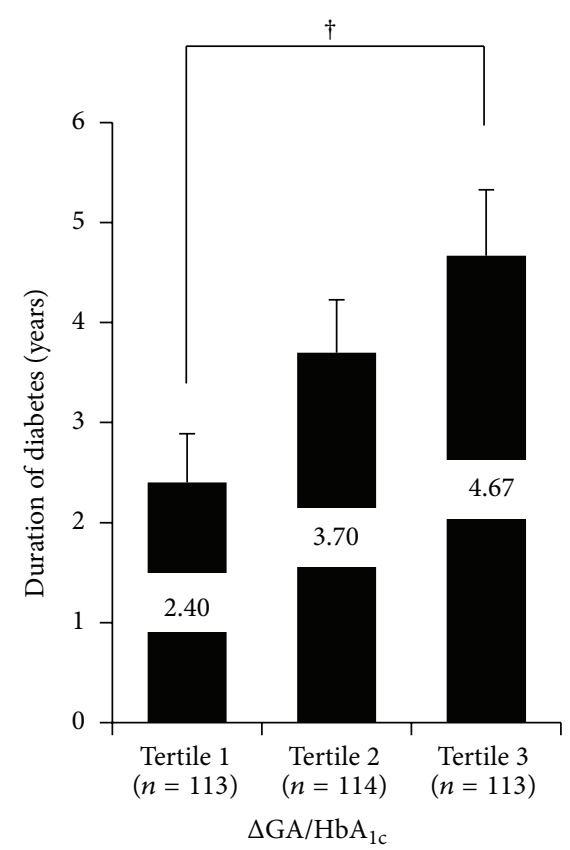

(a)

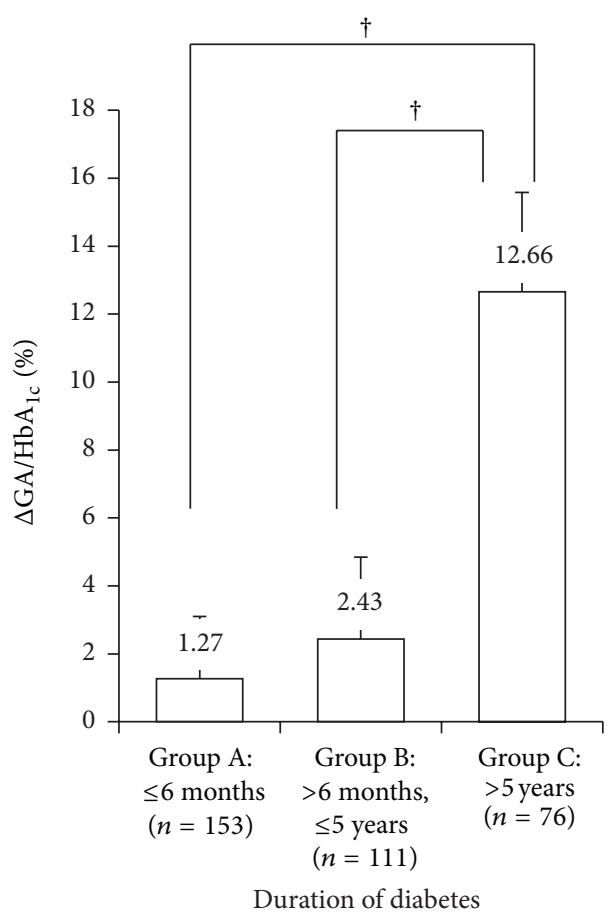

(c)

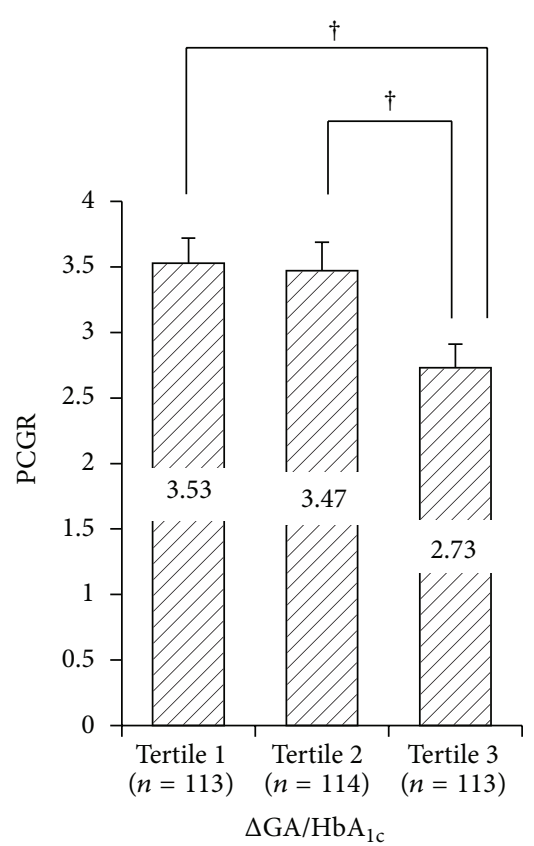

(b)

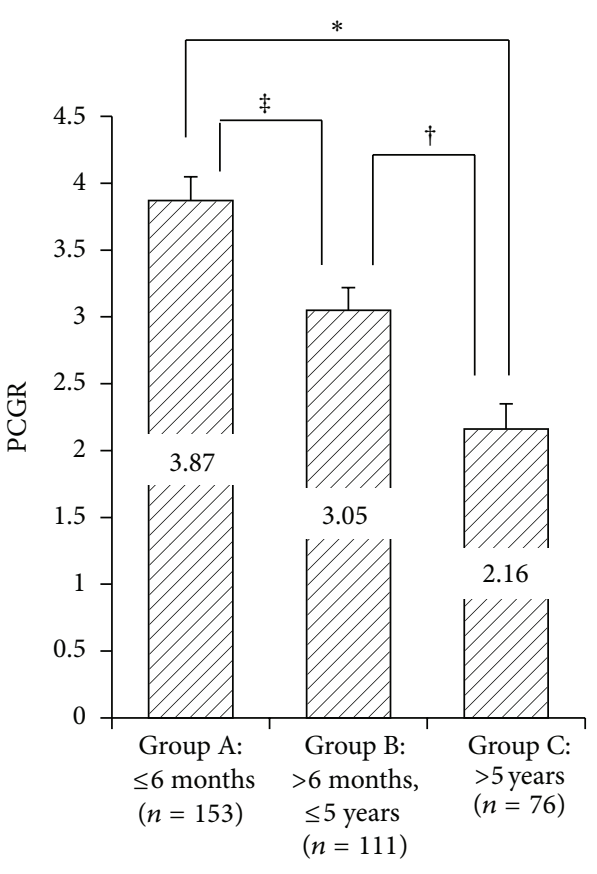

Duration of diabetes

(d)

Figure 2: Correlations between $\triangle \mathrm{GA} / \mathrm{HbA}_{1 \mathrm{c}}$ and duration of diabetes, beta-cell function. $(\mathrm{a}, \mathrm{b})$ Differences of duration of diabetes (a) and PCGR (b) in subjects according to the tertiles of $\Delta \mathrm{GA} / \mathrm{HbA}_{1 \mathrm{c}}$. (c, d) Differences of $\Delta \mathrm{GA} / \mathrm{HbA}_{1 \mathrm{c}}$ (c) and PCGR (d) in subjects according to duration of diabetes. ${ }^{\dagger} p<0.05,{ }^{\ddagger} p<0.01,{ }^{*} p<0.001 ; \Delta \mathrm{GA} / \mathrm{HbA}_{1 \mathrm{c}}(\%)=\Delta \mathrm{GA} / \mathrm{HbA}_{1 \mathrm{c}} /$ nadir point GA/HbA $1 \mathrm{c} * 100$.

$p=0.007)$ was more strongly associated with $\Delta \mathrm{GA} / \mathrm{HbA}_{1 \mathrm{c}}$ than $\Delta$ C-peptide (STD $\beta=-0.139, p=0.011)$.

We classified study subjects according to tertiles of $\Delta \mathrm{GA} / \mathrm{HbA}_{1 \mathrm{c}}$. Individuals in higher tertiles for $\Delta \mathrm{GA} / \mathrm{HbA}_{1 \mathrm{c}}$ had longer duration of diabetes (2.4 versus 3.7 versus 4.7 years; tertile 1 versus tertile $3, p=0.013$ ) and lower levels of
PCGR (3.5 versus 3.5 versus 2.7; tertile 1 versus tertile $3, p=$ 0.011 ; tertile 2 versus tertile $3, p=0.021$ ) (Figures 2(a) and 2(b)). Moreover, study subjects were categorized into three groups based on duration of diabetes (Group A: $\leq 6$ months, $n=153$; Group B: $>6$ months and $\leq 5$ years, $n=111$; Group C: $>5$ years, $n=76$ ) to investigate the impact of diabetes 
TABLE 3: Multivariable linear regression analyses to determine the variables associated with $\Delta \mathrm{GA} / \mathrm{HbA}_{1 \mathrm{c}}$.

\begin{tabular}{|c|c|c|c|c|c|c|c|c|c|c|}
\hline \multirow{3}{*}{ Variables } & \multicolumn{2}{|c|}{ Model 1} & \multirow{2}{*}{\multicolumn{2}{|c|}{$\begin{array}{l}\text { Model } 2 \\
\text { Model } 1 \\
+ \text { PCGR }\end{array}$}} & \multicolumn{2}{|c|}{ Model 3} & \multicolumn{2}{|c|}{ Model 4} & \multicolumn{2}{|c|}{ Model 5} \\
\hline & Conventio & onfounders & & & $\begin{array}{r}\mathrm{M} \\
+ \text { duratio }\end{array}$ & $\begin{array}{l}2 \\
\text { diabetes }\end{array}$ & $\begin{array}{r}\mathrm{M} \\
+\mathrm{m}\end{array}$ & $\begin{array}{l}3 \\
\text { GA }\end{array}$ & $\begin{array}{r}\mathrm{M} \\
+\mathrm{me}\end{array}$ & $\begin{array}{l}3 \\
\mathrm{HbA}_{\mathrm{lc}}\end{array}$ \\
\hline & $\operatorname{STD} \beta$ & $p$ & $\operatorname{STD} \beta$ & $p$ & $\operatorname{STD} \beta$ & $p$ & $\operatorname{STD} \beta$ & $p$ & $\operatorname{STD} \beta$ & $p$ \\
\hline $\begin{array}{l}\text { DPP-IV } \\
\text { inhibitor use }\end{array}$ & -0.111 & 0.049 & -0.109 & 0.053 & -0.089 & 0.111 & -0.084 & 0.133 & -0.088 & 0.116 \\
\hline PCGR & - & - & -0.161 & 0.009 & -0.111 & 0.080 & -0.059 & 0.396 & -0.106 & 0.113 \\
\hline $\begin{array}{l}\text { Duration of } \\
\text { diabetes }\end{array}$ & - & - & & & 0.172 & 0.005 & 0.166 & 0.007 & 0.170 & 0.007 \\
\hline
\end{tabular}

Conventional confounders: age (years), sex $\left(0=\right.$ female, $1=$ male), body mass index $\left(\mathrm{kg} / \mathrm{m}^{2}\right)$, waist circumference $(\mathrm{cm})$, and estimated glomerular filtration rate $\left(\mathrm{mL} / \mathrm{min} / 1.73 \mathrm{~m}^{2}\right)$.

PCGR, postprandial C-peptide to glucose ratio; STD $\beta$, standardized $\beta$ coefficient. Values with statistical significance are printed in bold.

duration on $\Delta \mathrm{GA} / \mathrm{HbA}_{1 \mathrm{c}}$ ratio and PCGR. The $\Delta \mathrm{GA} / \mathrm{HbA}_{1 \mathrm{c}}$ ratios (expressed as percentages) were significantly elevated in patients with diabetes of duration $>5$ years compared to other groups (Figure 2(c)), whereas PCGR was decreased in patients with longer duration of diabetes (Figure 2(d)).

\section{4. $\triangle \mathrm{GA} / \mathrm{Hb} \mathrm{A}_{1 c}$ Was Independently Associated with Duration} of Diabetes. Multivariable linear regression models were applied to determine the clinical and laboratory variables associated with $\Delta \mathrm{GA} / \mathrm{HbA}_{1 \mathrm{c}}$ (Table 3 ). We focused on certain parameters that can directly or indirectly reflect the insulin secretory function, such as PCGR, duration of diabetes, and medication history of DPP-IV inhibitor which can effectively reduce postprandial glucose. After adjustment for clinically important variables such as age, sex, BMI, waist circumference, and estimated GFR in model 1, history of DPPIV inhibitor use was negatively associated with $\Delta \mathrm{GA} / \mathrm{HbA}_{1 \mathrm{c}}$ (STD $\beta=-0.111, p=0.049$ ). After additional inclusion of PCGR in model 2, PCGR showed significant correlation with $\Delta \mathrm{GA} / \mathrm{HbA}_{1 \mathrm{c}}$ (STD $\left.\beta=-0.161, p=0.009\right)$, but history of DPPIV inhibitor use lost its significance. In model 3, duration of diabetes was further adjusted and the significant correlation of PCGR with $\Delta \mathrm{GA} / \mathrm{HbA}_{1 \mathrm{c}}$ disappeared (STD $\beta=-0.111, p=$ $0.080)$. However, duration of diabetes was still independently associated with $\Delta \mathrm{GA} / \mathrm{HbA}_{1 \mathrm{c}}$ (STD $\left.\beta=0.172, p=0.005\right)$. Moreover, this association remained significant even after adjustment for glycemic status of subjects (inclusion of mean GA in model 4 and mean $\mathrm{HbA}_{1 \mathrm{c}}$ in model 5, resp.).

Additionally, we conducted multiple linear regression analyses to determine variables associated with PCGR at baseline (Supplementary Table 1 in Supplementary Material available online at http://dx.doi.org/10.1155/2015/576306). PCGR showed the strongest relationship with mean GA (STD $\beta=-0.336, p<0.001)$. It also had significant correlation with duration of diabetes (STD $\beta=-0.133, p=0.010$ ) and insulin use (STD $\beta=-0.119, p=0.029$ ) (model 1). To evaluate the association between PCGR and $\Delta \mathrm{GA} / \mathrm{HbA}_{1 \mathrm{c}}$, model 2 was developed, which showed a significant negative relationship (STD $\beta=-0.107, p=0.032$ ).

\section{Discussion}

Evidence has accumulated on the clinical relevance of GA as a glycemic index. However, the optimal use of GA as a glucose monitoring tool has not been fully investigated. Based on a previous cross-sectional study that showed that GA values are significantly influenced by the duration of T2D in cases where beta-cell function gradually decreases with time, we hypothesized that the ratio of $\mathrm{GA}$ to $\mathrm{HbA}_{1 \mathrm{c}}$ might not be constant over time. In this study of more than 4 years, we assessed glycemic excursion by measuring $\mathrm{HbA}_{1 \mathrm{c}}$ and GA and investigated discrepancy between two glycemic indices according to multiple time points. This study has three main findings: first, we found an initial sharp decrease in these glycemic indices, followed by maintenance at a low level, and then a gradual increase. Unlike for $\mathrm{GA}$, the $\mathrm{HbA}_{1 \mathrm{c}}$ increase was statistically insignificant. Second, the change in $\mathrm{GA} / \mathrm{HbA}_{1 \mathrm{c}}$ ratios, defined as the difference between the nadir point and the end point, was independently associated with baseline duration of diabetes. Third, impaired betacell function accounted for the association between longer duration of diabetes and increase in GA relative to $\mathrm{HbA}_{1 \mathrm{c}}$, as well as the increase in the $\mathrm{GA} / \mathrm{HbA}_{1 \mathrm{c}}$ ratio.

Because $\mathrm{HbA}_{1 \mathrm{c}}$ is formed via a nonenzymatic glycation process of hemoglobin in erythrocytes [12], medical conditions such as pregnancy, hemolytic anemia, chronic kidney disease, or end stage renal disease with dialysis could alter $\mathrm{HbA}_{1 \mathrm{c}}$ levels. In those cases, GA may be a more reliable marker than $\mathrm{HbA}_{1 \mathrm{c}}$ [5]. In contrast to $\mathrm{HbA}_{1 \mathrm{c}}$ formation, which requires intracellular glucose and protein metabolism, GA is formed directly via an extracellular nonenzymatic glycation process in plasma. However, medical conditions associated with albumin metabolism such as obesity, hyperthyroidism, and nephrotic syndrome, as well as glucocorticoid treatment [5], are known to affect GA levels. To avoid complications, we did not include patients with liver cirrhosis, chronic kidney diseases, pregnancy, and hematologic disorders or those who were being treated with steroid therapy.

With respect to the clinical relevance of the $\mathrm{GA} / \mathrm{HbA}_{1 \mathrm{c}}$ ratio, it is known that the ratio is significantly correlated with insulin secretory beta-cell function but not with insulin resistance [6]. Recent study also showed that lower insulin secretory capacity predicted increased levels of $\mathrm{GA} / \mathrm{HbA}_{1 \mathrm{c}}$ ratio in subjects with T2D [13]. Moreover, the GA/HbA ratio in patients with T1D and T2D more accurately reflected glucose excursion $[7,14-16]$ and diabetic vasculopathy $[8,17]$ than $\mathrm{HbA}_{1 \mathrm{c}}$ alone. The $\mathrm{GA} / \mathrm{HbA}_{1 \mathrm{c}}$ ratio was significantly 
higher in T2D patients treated with insulin than in those treated with either diet or oral hypoglycemic agents [7, 18]. This observation might explain why history of insulin use is associated with either significant hyperglycemia or decreased beta-cell function. Our study also showed that $\Delta \mathrm{GA} / \mathrm{HbA}_{1 \mathrm{c}}$ between end point and nadir point is significantly associated with decreased insulin secretory function-related clinical and laboratory variables such as baseline and mean GA, mean $\mathrm{HbA}_{1 \mathrm{c}}$ PCGR, $\triangle$ C-peptide, and diabetic duration (Table 2). Of the assessed glycemic indices, baseline $\mathrm{HbA}_{1 \mathrm{c}}$ did not predict the changes in the $\mathrm{GA} / \mathrm{HbA}_{1 \mathrm{c}}$ ratio. With respect to the effect of insulin secretory factors on GA values, a recent cross-sectional study reported that GA levels significantly increased more in patients with longer duration of T2D and impaired beta-cell function measured by $\Delta \mathrm{C}$ peptide regardless of $\mathrm{HbA}_{1 \mathrm{c}}$ levels [11]. Consistent with this finding, our longitudinal study also showed that patients with higher levels of $\Delta \mathrm{GA} / \mathrm{HbA}_{1 \mathrm{c}}$ had longer duration of diabetes and lower levels of PCGR (Figure 2). Furthermore, PCGR representing beta-cell function was associated with diabetic duration and insulin use at baseline and mean GA but not with mean $\mathrm{HbA}_{1 \mathrm{c}}$. Based on these findings, we could infer that patients with T2D of longer duration and with higher $\mathrm{GA} / \mathrm{HbA}_{1 \mathrm{c}}$ are more likely to have impaired beta-cell function and need insulin.

Our study had several strengths. First, this study is a longitudinal study with a long follow-up period of more than 4 years, which allowed us to investigate the changes in GA and $\mathrm{HbA}_{1 \mathrm{c}}$ levels over time. Second, about $80 \%$ of participants had a relatively short duration of diabetes $(\leq 5$ years) at enrollment. Lastly, we conducted mixed meal tests to obtain basal and stimulated C-peptide levels, which were then used to calculate PCGR as a measure of beta-cell function. That allowed for standardization of the stimulation calories and glucose content. Because it can be easily calculated and is a reliable indicator of beta-cell function, the PCGR is being used more frequently to help determine the optimal antidiabetic drug treatment $[19,20]$. In our study, PCGR levels were strongly associated with $\Delta$ C-peptide $(r=0.808, p<0.001)$ which strongly predicted beta-cell function (Supplementary Figure 1). In multivariable linear regression analyses, PCGR was also associated with $\triangle \mathrm{GA} / \mathrm{HbA}_{1 \mathrm{c}}$. However, because the duration of diabetes strongly affects $\Delta \mathrm{GA} / \mathrm{HbA}_{1 \mathrm{c}}$, after adjusting for duration of diabetes, the association between $\triangle \mathrm{GA} / \mathrm{HbA}_{1 \mathrm{c}}$ and PCGR disappeared (Table 3).

This study has the following limitations. First, we did not measure beta-cell function or glucose levels during followup period or at the end point. Thus, we did not prove that the difference between GA and $\mathrm{HbA}_{1 \mathrm{c}}$ is caused by a decline in beta-cell function during the follow-up period. Second, since this is a retrospective study, the follow-up period varied among the participants. Third, because we did not assess changes in medication, we could not adjust for its effects.

\section{Conclusions}

We conclude that both impaired beta-cell function and longer duration of diabetes are associated with an increase in GA relative to $\mathrm{HbA}_{1 \mathrm{c}}$ and an increase in the $\mathrm{GA} / \mathrm{HbA}_{1 \mathrm{c}}$ ratio. The $\mathrm{GA} / \mathrm{HbA}_{1 \mathrm{c}}$ ratio was significantly correlated with insulin secretory beta-cell function and increased as duration of diabetes increased. In this regard, clinicians should be extra careful when interpreting $\mathrm{GA}$ and $\mathrm{GA} / \mathrm{HbA}_{1 \mathrm{c}}$ ratio values in subjects with longer duration of diabetes. Further welldesigned prospective studies enrolling larger populations are warranted.

\section{Conflict of Interests}

The authors declare that there is no competing financial interest associated with this paper.

\section{Authors' Contribution}

Byung-Wan Lee, Yong-ho Lee, and Hye-jin Yoon carried out the concept and design of the study. Hye-jin Yoon, Yong-ho Lee, So Ra Kim, Byung-Wan Lee, and Hyun Chul Lee carried out data analysis and interpretation. Hye-jin Yoon, Yong-ho Lee, and Byung-Wan Lee were responsible for the drafting of the paper. Kwang Joon Kim, Eun Seok Kang, Bong Soo Cha, and Hyun Chul Lee were responsible for the critical revision of the paper. Hye-jin Yoon, Yong-ho Lee, and Kwang Joon Kim were responsible for the statistics. Hye-jin Yoon and Yong-ho Lee were responsible for the data collection. Hye-jin Yoon and Yong-ho Lee contributed equally to this study.

\section{References}

[1] Y. K. Lee, S. O. Song, K. J. Kim et al., "Glycemic effectiveness of metformin-based dual-combination therapies with sulphonylurea, pioglitazone, or DPP4-inhibitor in drug-naïe Korean type 2 diabetic patients," Diabetes \& Metabolism Journal, vol. 37, no. 6, pp. 465-474, 2013.

[2] American Diabetes Association, "Standards of medical care in diabetes-2014," Diabetes Care, vol. 37, supplement 1, pp. S14S80, 2014.

[3] UK Prospective Diabetes Study (UKPDS) Group, "Intensive blood-glucose control with sulphonylureas or insulin compared with conventional treatment and risk of complications in patients with type 2 diabetes (UKPDS 33)," The Lancet, vol. 352, no. 9131, pp. 837-853, 1998.

[4] E. J. Lee, Y. J. Kim, T. N. Kim et al., "Alc variability can predict coronary artery disease in patients with type 2 diabetes with mean A1c levels greater than 7," Endocrinology and Metabolism, vol. 28, no. 2, pp. 125-132, 2013.

[5] K. J. Kim and B.-W. Lee, "The roles of glycated albumin as intermediate glycation index and pathogenic protein," Diabetes \& Metabolism Journal, vol. 36, no. 2, pp. 98-107, 2012.

[6] D. Kim, K. J. Kim, J. H. Huh et al., “The ratio of glycated albumin to glycated haemoglobin correlates with insulin secretory function," Clinical Endocrinology, vol. 77, no. 5, pp. 679-683, 2012.

[7] E. Y. Lee, B.-W. Lee, D. Kim et al., "Glycated albumin is a useful glycation index for monitoring fluctuating and poorly controlled type 2 diabetic patients," Acta Diabetologica, vol. 48, no. 2, pp. 167-172, 2011.

[8] S. O. Song, K. J. Kim, B.-W. Lee, E. S. Kang, B. S. Cha, and H. C. Lee, "Serum glycated albumin predicts the progression of 
carotid arterial atherosclerosis," Atherosclerosis, vol. 225, no. 2, pp. 450-455, 2012.

[9] S. Madsbad, O. K. Faber, C. Binder, P. McNair, C. Christiansen, and I. Transbøl, "Prevalence of residual beta-cell function in insulin-dependent diabetics in relation to age at onset and duration of diabetes," Diabetes, vol. 27, supplement 1, pp. 262264, 1978.

[10] C. C. Jensen, M. Cnop, R. L. Hull, W. Y. Fujimoto, and S. E. Kahn, " $\beta$-cell function is a major contributor to oral glucose tolerance in high-risk relatives of four ethnic groups in the U.S," Diabetes, vol. 51, no. 7, pp. 2170-2178, 2002.

[11] Y. H. Lee, M. H. Kown, K. J. Kim et al., "Inverse association between glycated albumin and insulin secretory function may explain higher levels of glycated albumin in subjects with longer duration of diabetes," PLoS ONE, vol. 9, no. 9, Article ID e108772, 2014.

[12] M. J. L. Hare, J. E. Shaw, and P. Z. Zimmet, "Current controversies in the use of haemoglobin $\mathrm{A}_{1 \mathrm{c}}$ " Journal of Internal Medicine, vol. 271, no. 3, pp. 227-236, 2012.

[13] Y. Saisho, K. Tanaka, T. Abe, T. Kawai, and H. Itoh, "Lower beta cell function relates to sustained higher glycated albumin to glycated hemoglobin ratio in Japanese patients with type 2 diabetes," Endocrine Journal, vol. 61, no. 2, pp. 149-157, 2014.

[14] T. Suwa, A. Ohta, T. Matsui et al., "Relationship between clinical markers of glycemia and glucose excursion evaluated by continuous glucose monitoring (CGM)," Endocrine Journal, vol. 57, no. 2, pp. 135-140, 2010.

[15] K. Yoshiuchi, M. Matsuhisa, N. Katakami et al., "Glycated albumin is a better indicator for glucose excursion than glycated hemoglobin in type 1 and type 2 diabetes," Endocrine Journal, vol. 55, no. 3, pp. 503-507, 2008.

[16] Y. Saisho, K. Tanaka, T. Abe, A. Shimada, T. Kawai, and H. Itoh, "Glycated albumin to glycated hemoglobin ratio reflects postprandial glucose excursion and relates to beta cell function in both type 1 and type 2 diabetes," Diabetology International, vol. 2, no. 3, pp. 146-153, 2011.

[17] W. Kim, K. J. Kim, B.-W. Lee, E. S. Kang, B. S. Cha, and H. C. Lee, "The glycated albumin to glycated hemoglobin ratio might not be associated with carotid atherosclerosis in patients with type 1 diabetes," Diabetes \& Metabolism Journal, vol. 38, no. 6, pp. 456-463, 2014.

[18] M. Koga, J. Murai, H. Saito, and S. Kasayama, "Glycated albumin and glycated hemoglobin are influenced differently by endogenous insulin secretion in patients with type 2 diabetes," Diabetes Care, vol. 33, no. 2, pp. 270-272, 2010.

[19] Y. Okuno, H. Komada, K. Sakaguchi et al., "Postprandial serum C-peptide to plasma glucose concentration ratio correlates with oral glucose tolerance test- and glucose clamp-based disposition indexes," Metabolism: Clinical and Experimental, vol. 62, no. 10, pp. 1470-1476, 2013.

[20] E. Y. Lee, S. Hwang, S. H. Lee et al., "Postprandial C-peptide to glucose ratio as a predictor of beta-cell function and its usefulness for staged management of type 2 diabetes," Journal of Diabetes Investigation, vol. 5, no. 5, pp. 517-524, 2014. 


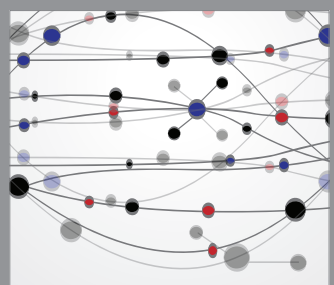

The Scientific World Journal
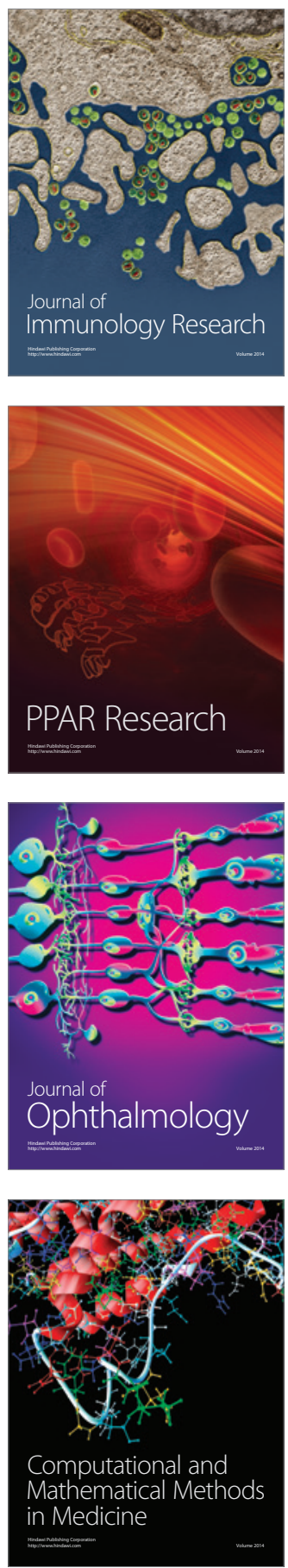

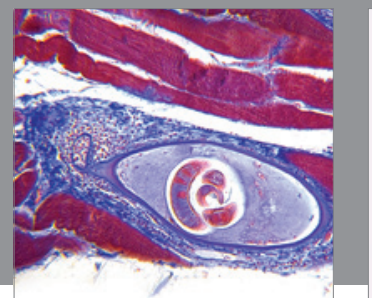

Gastroenterology

Research and Practice
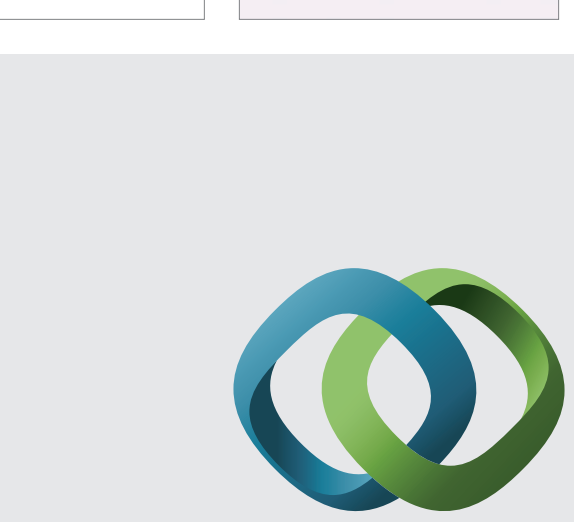

\section{Hindawi}

Submit your manuscripts at

http://www.hindawi.com
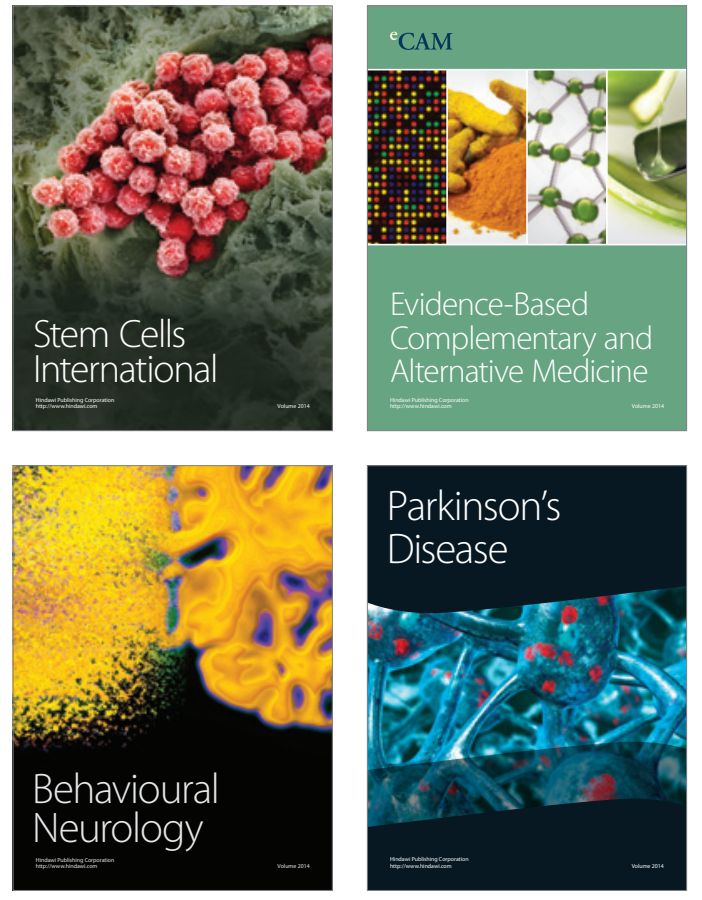
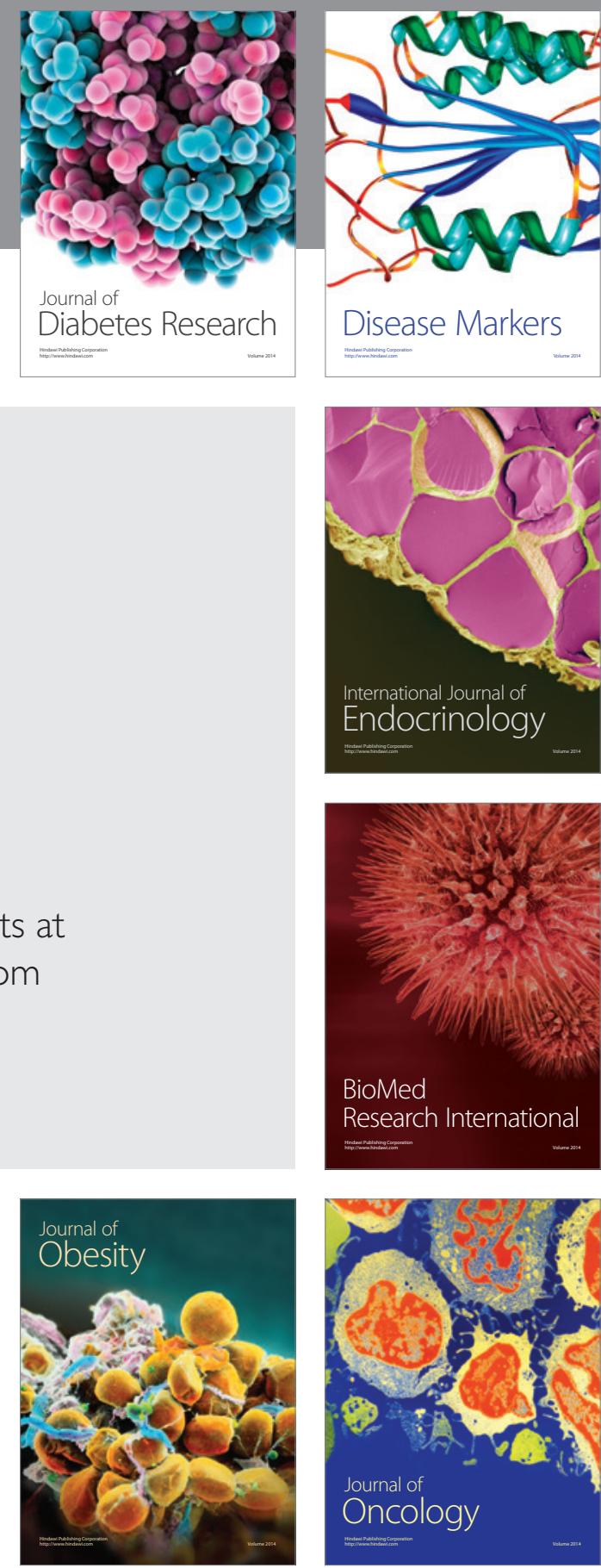

Disease Markers
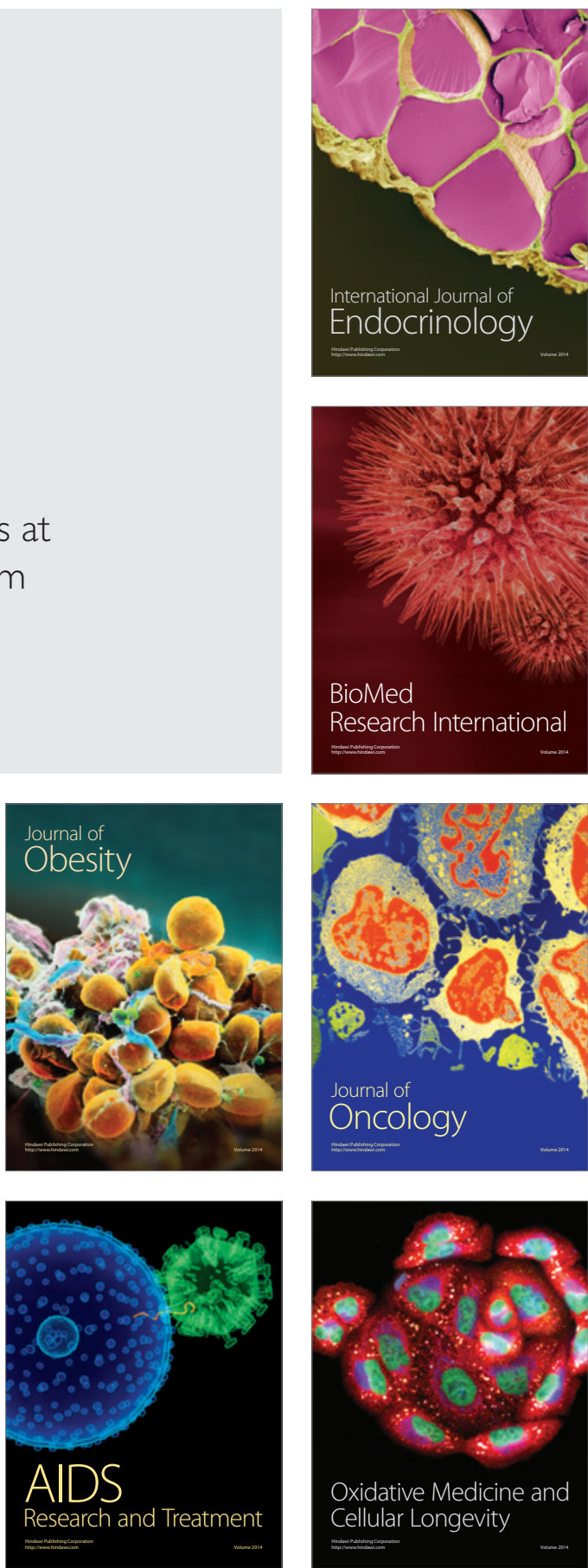